\title{
EFFECT OF TIME IN THE MOISTURE CHAMBER ON THE ANTHRACNOSIS SEVERITY IN Annona squamosa L. AND A. muricata L. LEAVES
}

\author{
Maria Erika Francisca de Sáles Oliveira ${ }^{1}$, Jaqueline Figueredo de Oliveira ${ }^{1}$, Jackeline Laurentino da Silva², \\ Mariote dos Santos Brito Netto ${ }^{3}$, Iraildes Pereira Assunção ${ }^{4}$, Gaus Silvestre Andrade Lima ${ }^{4}$ \\ ${ }^{1}$ Doutora em Proteção de Plantas da Universidade Federal de Alagoas, Centro de Ciências Agrárias - CECA, BR 104 Norte, Km 85, \\ Rio Largo, AL. CEP 57.000-100. \\ 2 Discente de Pós-Graduação em Proteção de Plantas da Universidade Federal de Alagoas, Centro de Ciências Agrárias - CECA, BR \\ 104 Norte, Km 85, Rio Largo, AL. CEP 57.000-100. \\ ${ }^{3}$ Doutor em Fitopatologia da Universidade Federal Rural de Pernambuco, Recife, PE. CEP 52.051-360. \\ ${ }^{4}$ Professor de Agronomia da Universidade Federal de Alagoas, Centro de Ciências Agrárias - CECA, BR 104 Norte, Km 85, Rio Largo, \\ AL. CEP 57.000-100. \\ Autor para correspondência: Maria Erika Francisca de Sáles Oliveira, mayerika@hotmail.com
}

\begin{abstract}
Edaphoclimatic conditions exert great influence on the development of pathogens; therefore, knowledge about pathogen, host and environment interaction for disease prevention systems and to define control actions is required. The aim of the present study was to evaluate the influence of time in moisture chamber on the anthracnose severity in sugar apple and soursop leaves. Two times of two and five days in moisture chamber at temperatures of 20,25 and $30^{\circ} \mathrm{C}$ were used. The experimental design was completely randomized in a triple factorial arrangement $(2 \times 5 \times 3)$, represented by two times in moisture chamber, five Colletotrichum species (C. fructicola, C. theobromicola, C. karstii, C. siamense and C. tropicale) three temperatures, with four replicates / leaf. The diameter of lesions was determined by measuring each lesion in two perpendicular directions on the second and fifth days. It was observed that in the time of 2 days of inoculation, there were no anthracnose symptoms in soursop and sugar apple leaves at any of temperatures tested. After times of 5 days, there was appearance of dark brown to black spots. Temperature of $25^{\circ} \mathrm{C}$ and time of 5 days favored the appearance of anthracnose symptoms in sugar apple (Annona squamosa L.) and soursop leaves (Annona muricata L.).
\end{abstract}

KEYWORDS: Colletotrichum, anonaceous, temperature.

\section{INFLUÊNCIA DE PERÍODOS DE PERMANÊNCIA EM CÂMARA ÚMIDA SOBRE A SEVERIDADE DA ANTRACNOSE EM FOLHAS DE Annona squamosa L. E A. muricata L.}

RESUMO: As condições edafoclimáticas exercem grande influência no desenvolvimento dos patógenos, devido a isso, se faz necessário conhecer sobre a interação patógeno, hospedeiro e ambiente para sistemas de prevenção de doenças e para definir ações de controle. 0 presente trabalho teve como objetivo avaliar a influência dos períodos de permanência em câmara úmida sobre a severidade da antracnose em folhas de pinheira e gravioleira. Foram utilizados dois períodos de permanência em câmara úmida de dois e cinco dias, nas temperaturas de 20,25 e $30{ }^{\circ} \mathrm{C}$. 0 delineamento experimental foi inteiramente casualizado em arranjo fatorial triplo $(2 \times 5 \times 3)$, representado por dois períodos de permanência em câmara úmida, cinco espécies de Colletotrichum (C. fructicola, C. theobromicola, C. karstii, C. siamense e C. tropicale) três temperaturas, com quatro repetições/folha. $O$ diâmetro das lesões foi determinado medindo-se cada lesão em dois sentidos perpendiculares, no segundo e quinto dia. Foi observada que no período de permanência de 2 dias de inoculação não houve sintomas de antracnose nas folhas de gravioleira e pinheira em nenhuma das temperaturas testadas. Após 5 dias de permanência, houve 0 aparecimento de manchas de coloração pardo-escura a preta. A temperatura de $25^{\circ} \mathrm{C}$ e o período de permanência de 5 dias favoreceu o aparecimento de sintomas de antracnose em folhas de pinheira (Annona squamosa L.) e gravioleira (Annona muricata L.).

PALAVRAS CHAVE: Colletotrichum, Annonaceae, temperatura. 


\section{INTRODUCTION}

Anthracnose, caused by Colletotrichum species, is considered the most frequent fungal disease in Annonaceae, causing losses of up to $70 \%$ in periods of prolonged rains (Junqueira; Junqueira, 2014; Kamei et al., 2014; Álvarez et al. 2014; Costa et al., 2019).

Species of the genus Colletotrichum as including Colletotrichum tropicale E.I. Rojas, S.A. Rehner \& Samuels, C. karstii L. Yang, Zuo Y. Liu, K.D. Hyde \& L. Cai,C. siamense Prihastuti, L. Cai \& K.D. Hyde, C. theobromicola Delacr., Bull, C. gigasporum E.F. Rakotoniriana \& Munaut, C. gloeosporioides (Penz) Penz. \& Sacc, C. fructicola Prihastuti, L. Cai \& K.D. Hydee C. brevisporum Phoulivong S., P. Noireung, L. Cai \& K. D. Hyde have been reported as etiological agents of anthracnose on Annona squamosa $L$. and $A$. muricata L. leaves in Brazil (Costa et al., 2017, Costa et al., 2019).

Knowledge on the effects of the environment on the development of pathogens can aid in disease management strategies. Information on environmental factors is valuable in the development of disease prevention systems and can contribute to defining control actions (Maia et al., 2011).

Temperature exerts influence on the development of fungi of the genus Colletotrichum on the mycelial growth by the diameter of lesions developed on the host, on sporulation and germination of conidia and formation of appressoria that are favored by temperatures of $25^{\circ} \mathrm{C}$ and period of 12 to 18 hours of moisture (Poltronieri, 2012; Tavares, Souza, 2005; Lopez, 2005). These factors affect the progression of the disease in plants (Silveira et al., 2001) and are able to regulate the rate at which epidemics develop (Poltronieri, 2012); however, there are few studies about Colletotrichum species.

Pathogens differ in their preference for high or low temperature, since it affects spore germination and the number of spores formed (Agrios, 2005).

Considering the importance of anonaceous species and the scarcity of studies in literature related to the effects of environmental conditions on the development of anthracnose, the aim of this study was to evaluate the influence of times in moisture chamber on the anthracnose severity in $A$. squamosa and $A$. muricata leaves.

\section{MATERIAL AND METHODS}

The work was conducted at the Laboratory of Molecular Phytopathology of the Department of Agricultural Sciences (CECA) of the Federal University of Alagoas (UFAL) located at km 85 of BR 101 Norte (9027'54.71"S - 35049'39.27" W), in the municipality of Rio Largo, state of Alagoas.

To evaluate the influence of times in moisture chamber, asymptomatic sugar apple ( $A$. squamosa) and soursop leaves ( $A$. muricata) were used, from 'Chacara das Anonáceas', located in the municipality of Maceió/AL and Department of Agricultural Sciences (CECA)/UFAL, respectively. Leaves were washed, disinfected and conditioned in plastic Gerbox box (11 $x 11 \times 3.5 \mathrm{~cm}$ ) containing filter paper moistened with 5 $\mathrm{mL}$ of autoclaved distilled water. To avoid contact with the moist surface, sterile Petri dish covers or bottoms were used and petioles were wrapped with cotton swab moistened with autoclaved distilled water to maintain leaf vigor and favor the germination of pathogen reproduction structures.

The inoculum consisted of BDA plugs $(5 \mathrm{~mm})$ removed from the borders of monosporic culture with seven days of growth, containing pathogen structures deposited equidistant from one another on the surface of asymptomatic leaves. Each isolate was inoculated separately in leaves with wounds from their respective hosts. Only BDA plugs without the pathogen were used as controls.

The experiment was kept in a Biochemistry Oxygen Demand (BOD) with temperatures of 20, 25, $30^{\circ} \mathrm{C} \pm 1{ }^{\circ} \mathrm{C}$ in the dark between 2 and 5 days. The experimental design was completely randomized in a triple factorial arrangement $(2 \times 5 \times 3)$, represented by two times in moisture chamber, five Colletotrichum species (C. fructicola, C. theobromicola, C. karstii, C. siamense and $C$. tropicale), three temperatures, with four replicates / leaf.

Colletotrichum isolates from sugar apple and soursop were obtained from the Collection of Phytopathogenic Fungi at the Universidade Federal de Alagoas (COUFAL).

After the times in moisture chamber, the diameter of lesions was determined by measuring the two perpendicular directions with the aid of a digital caliper. The mean values obtained were submitted to analysis of variance (ANOVA). The diameter of lesions 
caused by the different Colletotrichum species was compared by the Tukey test at $1 \%$ probability, using ASSISTAT 7.7 beta software.

\section{RESULTS AND DISCUSSION}

Treatments performed to evaluate the effect of temperature on the severity of Colletotrichum species on sugar apple leaves after 5 days in moisture chamber showed the appearance of dark brown spots with clearer center and irregular contour consistent with typical anthracnose symptoms at $25^{\circ} \mathrm{C}$ and $30^{\circ} \mathrm{C}$ and in soursop leaves, significant results at $1 \%$ probability level by the Tukey's test were observed (Figure 1 and 2). In the time of two days of inoculation, there were no anthracnose symptoms in sugar apple and soursop leaves at any of temperatures tested.

Figure 1. Evaluation of the five-day residence time in humid chamber of sweet apple $(A)$ and soursop leaves $(B)$ at different temperatures. $\mathrm{Ct}$ (Colletotrichum theobromicola), $\mathrm{Cf}$ (C. fructicola), $\mathrm{Ctr}$ (C. tropicale), $\mathrm{Cs}$ (C. siamense) and $\mathrm{Ck}$ (C. karsti). Means followed by the same letter do not differ from each other by the Tukey a test at $1 \%$ probability.
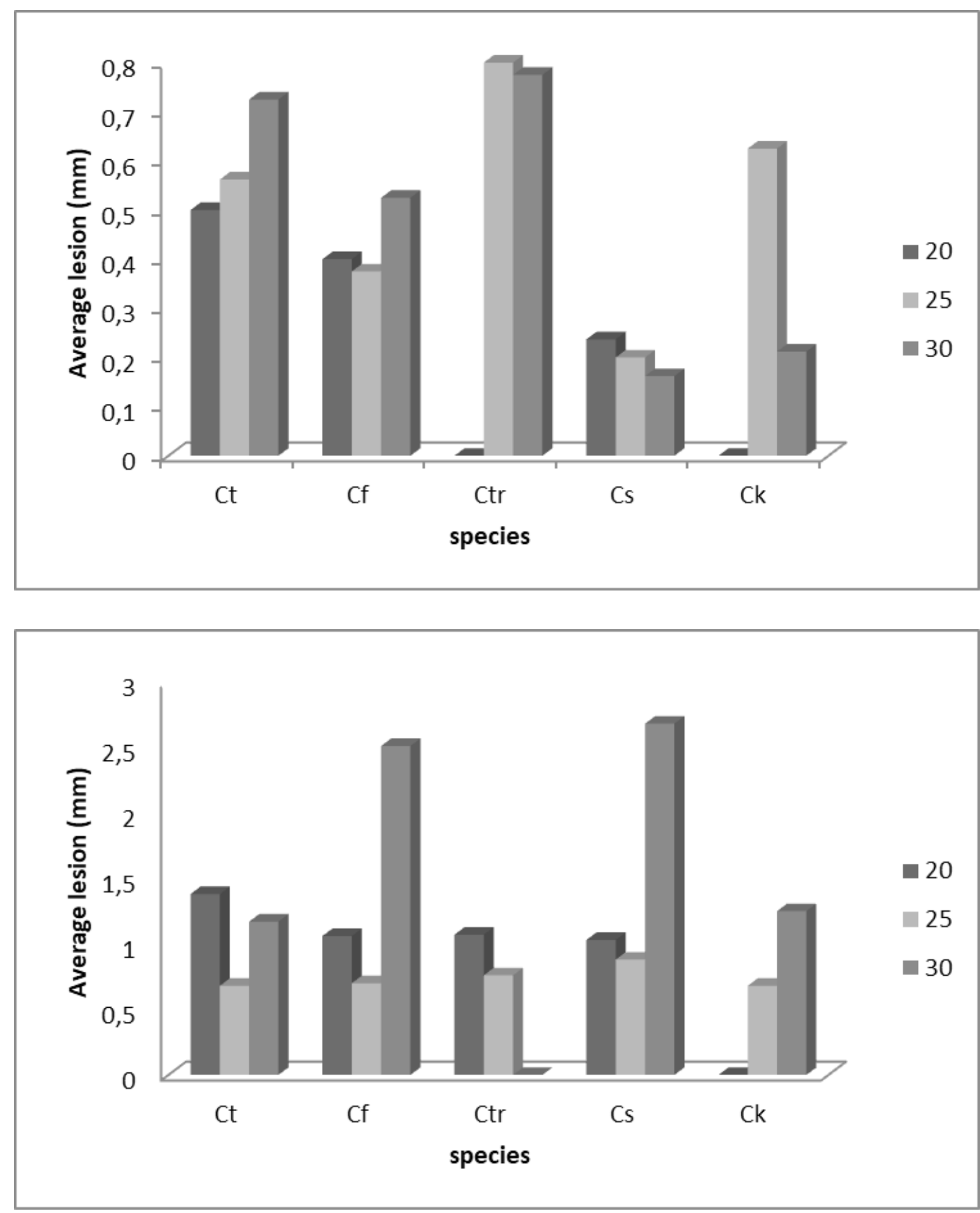
C. theobromicola, C. fructicola and C. siamense species caused symptoms at all temperatures tested. Anthracnose symptoms were not observed in sugar apple leaves inoculated with $C$. tropicale and $C$. karstii species when using temperature of $20{ }^{\circ} \mathrm{C}$. All Colletotrichum species caused typical anthracnose symptoms at temperatures of $25^{\circ} \mathrm{C}$ and $30^{\circ} \mathrm{C}$. However, temperature of $25^{\circ} \mathrm{C}$ provided greater severity in sugar apple leaves.

In soursop leaves after 5 days in moisture chamber, the appearance of dark brown to black spots was observed. C. theobromicola, C. tropicale, C. fructicolae $C$. siamense species caused anthracnose symptoms when submitted to temperature of $20^{\circ} \mathrm{C}$, except for C. karstii species. All species caused anthracnose symptoms in soursop leaves when submitted to temperature of $25^{\circ} \mathrm{C}$. At temperatures of $30^{\circ} \mathrm{C}$, C. siamense, C.fructicola, C. theobromicolae C. kasrtii species caused anthracnose symptoms; however, symptoms were not observed for $C$. tropicale.

Maia (2011) observed that Colletotrichum isolates obtained from mango showed better development when submitted to temperatures of $20^{\circ} \mathrm{C}$ and $25^{\circ} \mathrm{C}$. The ideal temperature for vegetative growth in most Colletotrichum species is in the range from 25 ${ }^{\circ} \mathrm{C}$ to $30{ }^{\circ} \mathrm{C}$ (SUTTON, 1992).

Soares et al. (2008) reported that temperature influences the speed of conidia germination, appressoria formation, penetration and colonization of $C$. acutatum and Colletotrichum gloeosporioidese, causal agents of anthracnose in guava. In C. gloeosporioides isolates obtained from solanaceae, it was observed that the development of colonies occurred at temperatures from $25^{\circ} \mathrm{C}$ and $28^{\circ} \mathrm{C}$ (TOZZE JUNIOR et al., 2006). Araújo et. al., 2006, reported that the intensity of the disease in cotton seeds is not influenced by the time of exposure to the pathogen, with temperature being the determining factor. Low temperatures lead to the paralysis of the pathogen activities or even death, and very high temperatures can cause the desiccation of fungal structures present in the source of inoculum (BEDENDO; AMORIM, 2011).

The results of this work demonstrate the influence of temperature, time in the moisture chamber on the severity of Colletotrichum species, showing that the temperature of $25{ }^{\circ} \mathrm{C}$ and the times of five days in the moisture favored the appearance of anthracnose symptoms in sugar apple ( $A$. squamosa) and soursop leaves (A. muricata).

\section{ACKNOWLEDGMENTS}

The present work was carried out with the support from the Coordination of Improvement of Higher Education Personnel - Brazil (CAPES) - Financing Code 001. We also thank the support from the Research Foundation of the State of Alagoas - FAPEAL.

\section{REFERENCES}

Agrios, G. Plant Pathology. 5 th ed. Academic. 2005.

Álvarez, E., Gañán, L., Rojas-Triviño, A., Mejía, J.F., Liano, G.A., \& González, A. Diversity and pathogenicity of Colletotrichum species isolated from soursop in Colombia. Plant Pathology, 2014, 139, 325-338.

Araújo, D. V.;Pozza, E. A.; Machado, J.C.;Zambenedetti, E.B.; Celano, F.A.O.; Carvalho, E.M.; Camargos, V.N. Influência da temperatura e do tempo de inoculação das sementes de algodão na transmissibilidade de Colletotrichum gossypii var. cephalosporioides. Fitopatologia brasileira [online], 2006, 31, 1, 35-40.

Bedendo, I. P.; Amorim, L. Ambiente e doença. In: Amorim, L.; Rezende, J. A. M.; Bergamin Filho, A. Manual de Fitopatologia: Princípios e conceitos. 2011, v. 01. 7, 133-147.

Costa, J. F. O.; Ramos-Sobrinho, R.; Chaves, T. P.; Silva, J. R. A.; Pinho D. B.; Assunção, I. P.; Lima, G.S.A. First Report of Colletotrichum fructicola causing anthracnose on Annona leaves in Brazil. Plant Disease, 2017, 2, 101.

Costa, J. F. O.; Kamei, S. H.; Silva, J. R. A.; Miranda, A.R.S.; Netto, M.B.; Silva, S.J.C.; Correia, K.C.; Lima, G.S.A.; Assunção, I.P. Species diversity of Colletotrichum infecting Annona spp. in Brazil. ISSN: 1573-8469. European Journal of Plant Pathology, 2019.

Dias, M. D.; Pozza, E. A.; Abreu, M. S.; Orosco-Miranda, E. Efeito da temperatura no crescimento micelial, produção e germinação de conídios de Colletotrichum spp. isolados de Coffea arabica L. Ciência Agrotécnica, $2005,29,3,545-552$.

Junqueira, N. T. V.; Junqueira, K. P. Principais doenças de anonáceas no Brasil: Descrição e Controle. 2014, v. 
36, edição especial, 55-64.

Kamei, S. H.; Costa, J. F. O.; Brito Netto, M.S.; Assunção, I.P.; Lima, G.S.A. Identificação e caracterização de espécies de Colletotrichum associadas à antracnose de anonáceas no estado de Alagoas. Revista Brasileira de Fruticultura, 2014, 36, ed. especial, 209-216.

Leite, R. M. V. B. C.; Amorim, L. Elaboração e validação de escala diagramática para mancha de alternaria em girassol. Summa Phytopathologica, 2002, 28, 14-19.

Lopez, A. M. Q. Doenças das anonáceas e do urucuzeiro. p. 73-77. In: Kimati, H.; Amorim, L.; Rezende, J. A. M.; Bergamin Filho, A.; Camargo, L. E. A. Manual de Fitopatologia. 2005, 2, 663.

Maia, F.G.M., Armesto, C., Antonio Zancan, W. L., Maia, J. B., \& Sobral de Abreu, M. Efeito da temperatura no crescimento micelial, produção, germinação de conídios de Colletotrichum spp. isolados de mangueira com sintomas de antracnose. Bioscience Journal, 2011, 27, 205-210.

Poltronieri, T. P. S. Patogenicidade, efeito da temperatura no desenvolvimento e controle de isolados de Colletotrichum gloeosporioides, agente causadores da antracnose da Juçara (Euterpe edulis Mart.). Dissertação (Mestrado em Fitopatologia Aplicada). Universidade Federal do Rio de Janeiro. 2012.
Silveira, N. S. S. Michereff, S. J., Mariano, R.L.R., Tavares, L.A. \& Maia, L. C. Influência da temperatura, período de molhamento e concentração do inoculo de fungos na incidência de podridões pós-colheita em frutos de tomateiro. Fitopatologia Brasileira, 2001, 26, 33-38.

Soares, A. R.; Lourenço, S. A.; Amorim, L. Infecção de goiabas por Colletotrichum gloeosporioides e Colletotrichum truncatum sob diferentes temperaturas e períodos de molhamento. Tropical Plant Pathology, 2008, 33, 265- 272.

Sutton, B.C. The genus Glomerella and its anamorph Colletotrichum. In: Bailey, J. A.; Jeger, M. J. Colletotrichum: biology, pathology and control. $C A B$ International: Wallingford, United Kingdom. 1992, 1-26.

Tavares, G. M.; Souza, P. E. de. Efeito de fungicidas no controle in vitro de Colletotrichum gloeosporioides, agente etiológico da antracnose do mamoeiro (Caricapapaya L.). Ciência e Agrotécnica, 2005, 29, 52-59.

Tozze Junior, H. J.; Mello, B.A.; Massola-Junior, N.S. Caracterização morfológica e fisiológica de isolados de Colletotrichum sp. causadores de antracnose em solanáceas. Summa Phytopathologica, 2006, 32, 77-79. 
